\title{
Submerged macrophytes as bioindicators of environmental conditions in shallow lakes in eastern Poland
}

\author{
Monika Tarkowska-Kukuryk* and Tomasz Mieczan* \\ Department of Hydrobiology, University of Life Sciences, Dobrzańskiego 37, 20-262 Lublin, Poland
}

Received 27 April 2016; Accepted 4 November 2016

\begin{abstract}
We investigated the responses of submerged macrophytes to environmental conditions in shallow lakes to evaluate the role of macrophytes as bioindicators of water quality and anthropogenic disturbances (such as eutrophication) of shallow lake ecosystems. The studies were conducted on a group of ten shallow lakes situated on the area of Polesie Lubelskie (eastern Poland). The lakes represented five types of macrophyte communities, Chara-Stratiotes-, Myriophyllum-, Potamogeton- and Ceratophyllum-dominated. The total biomass of macrophytes and their distribution were significantly negatively correlated with the trophic status of the lake. Principal component analysis confirms the separation of the lakes with regard to trophic status and macrophyte species richness and biomass. The results of the Monte Carlo permutation test (RDA analysis) indicated the significant effect of Secchi disc depth, $\mathrm{pH}$, conductivity, chlorophyll- $a, P_{\text {tot }}$, $\mathrm{P}-\mathrm{PO}_{4}, \mathrm{~N}-\mathrm{NO}_{3}$ and $\mathrm{N}-\mathrm{NH}_{4}$ on the biomass and distribution of submerged macrophytes in the lakes.
\end{abstract}

Key words: Macrophytes / bioindicators / environmental conditions / shallow lakes

\section{Introduction}

Submerged macrophytes constitute a key element in the functioning of shallow lakes and promote clear water conditions (Scheffer et al., 1993; Jeppesen et al., 2007). Macrophytes provide a refuge for small animals against predation, change the nutrient dynamics of the ecosystem, and prevent resuspension of the sediments, thus regulating water turbidity with consequences for physicochemical water quality and biotic communities (Kristensen et al., 1992; Horppila and Nurminen, 2001).

One of the most important ways in which macrophytes influence the lake status is their role in nutrient cycling. Due to the production of high biomass, aquatic plants have a high capacity for accumulation of biogenic compounds (Clarke and Wharton, 2001; Abdo and Da Silva, 2002). In general, the structural complexity and biomass of submerged macrophytes are regulated by nutrient enrichment. Phosphorus and nitrogen control are of great importance in maintaining the biodiversity of lake ecosystems. Phosphorus is considered to be a major determinant of primary production in lakes, particularly for phytoplankton (Kalff, 2001). The relationship between total phosphorus and chlorophyll- $a$ concentrations in

*Corresponding author: monika.kukuryk@up.lublin.pl, tomasz.mieczan@up.lublin.pl water is strongly affected by the percentage of water column and bottom area infested by macrophytes (Canfield et al., 1984; Faafeng and Mjelde, 1998). Nitrogen, which may be lost through denitrification processes within lake ecosystems, appears to be a limiting factor for some macrophytes and algal populations in macrophyte-dominated shallow lakes (James et al., 2005; Moss et al., 2005). Under nutrient enrichment, changes of macrophyte structure follow the general sequence of growth forms: from charophytes via elodeids to phytoplankton. In shallow hypertrophic lakes, submerged species are absent or reduce to one or two species appearing in the form of stray shoots or small patches (Rørslett, 1991; Toivonen and Huttunen, 1995; Egertson et al., 2004).

Macrophytes are known to be confined to specific habitats and react to many different changes in their optimal habitat (Barko et al., 1986; Murphy, 2002; van Geest, 2005). It is therefore often suggested that macrophytes are sensitive to anthropogenic disturbances, including sedimentation (Mahaney et al., 2004), hydrological modifications (Squires and van der Valk, 1992) and eutrophication (Penning et al., 2008) and can be used as an indicator assemblage.

Eutrophication, as a human-induced factor, affects the trophic status of shallow lake ecosystems in Europe. Such negative relations are observed in the Polesie Lubelskie region (eastern Poland) (Kornijów and Radwan, 2002; 


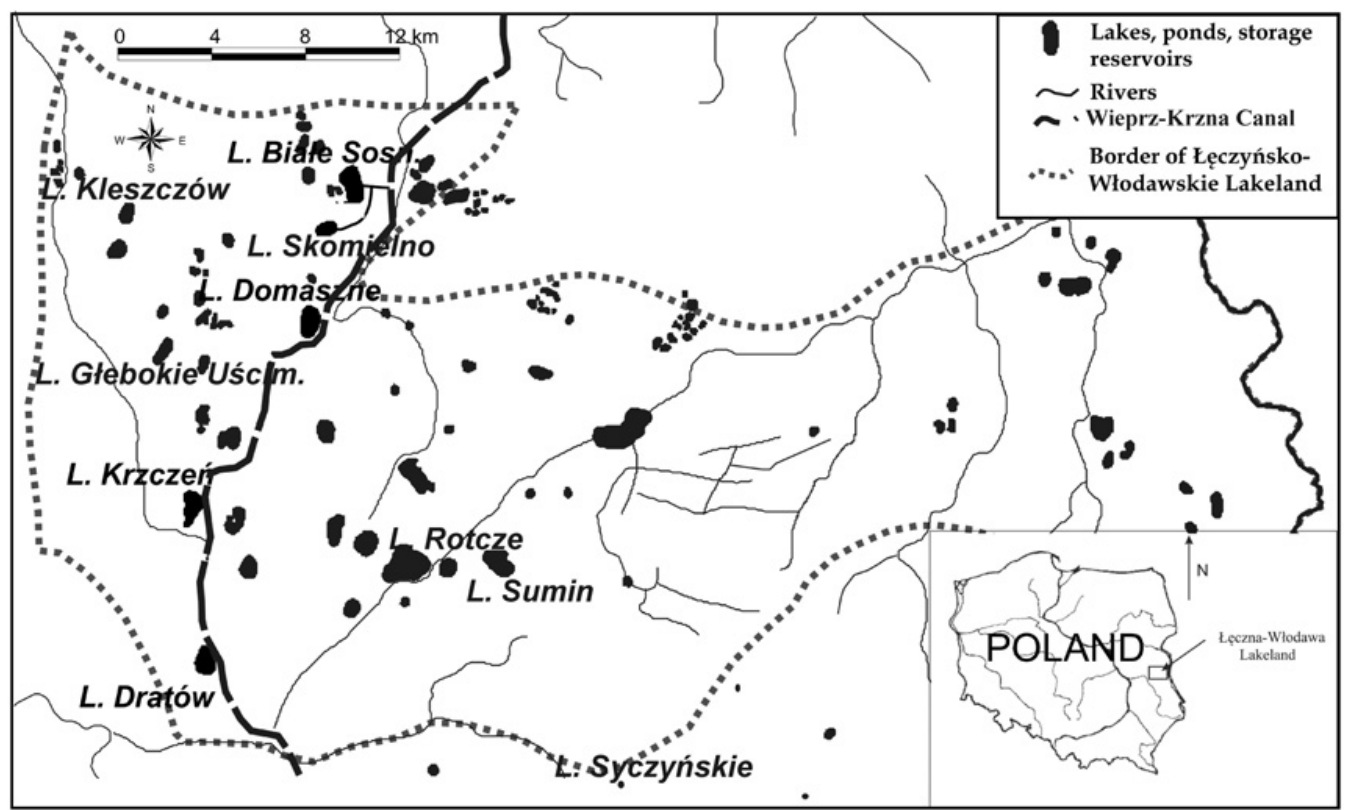

Fig. 1. Location of studied lakes. Kleszczów - Char_lake; Rotcze - Strat_lake 1; Skomielno - Strat_lake 2; Sumin - Myr_lake; Głębokie Uścimowskie-Cer_lake 1; Domaszne - Cer_lake 2; Krzczeń - Cer_lake 3; Syczyńskie - Cer_lake 4; Białe Sosnowickie Pot_lake 1; Dratów - Pot_lake 2.

Small et al., 2005). Intensive external loading of nutrients comes from catchments, used mainly for agriculture purposes, animal production and recreational activity, and causes deterioration in the water quality of many lakes. Highly productive lakes are often characterized by permanent and long-lasting cyanobacteria blooms. The group of shallow Polesie lakes is very specific; the origin of these lakes is not clear and still debated (the lakes are situated beyond the range of the last glaciation) (Kolada et al., 2005). As a result, the study of the relationships between environmental variables and macrophyte diversity in terms of eutrophication processes will make a significant contribution to the monitoring of shallow lake ecosystems.

As a consequence, the aim of the work described in this paper was to determine the links between the physical and chemical variables of the lakes and the diversity of submerged macrophytes, in an attempt to evaluate the potential of these plants as biological indicators of the environmental conditions of shallow lakes.

The specific objectives of the study were to: (1) describe species structure, biomass and spatial distribution of submerged macrophytes; (2) analyze the relations between macrophyte diversity and trophic state of the lakes; and (3) recognize the significant habitat conditions (environmental variables) affecting macrophyte structure and distribution.

\section{Materials and methods}

\section{Study area}

The study was conducted in ten shallow, polymictic lakes situated in the area of Polesie Lubelskie (eastern
Poland); Kleszczów $\left(51^{\circ} 31^{\prime} \mathrm{N}, 22^{\circ} 53^{\prime} \mathrm{E}\right)$, Rotcze $\left(51^{\circ} 22^{\prime} \mathrm{N}\right.$, $\left.23^{\circ} 06^{\prime} \mathrm{E}\right)$, Skomielno $\left(51^{\circ} 29^{\prime} \mathrm{N}, \quad 23^{\circ} 00^{\prime} \mathrm{E}\right)$, Głębokie Uścimowskie $\left(51^{\circ} 28^{\prime} \mathrm{N}, 22^{\circ} 55^{\prime} \mathrm{E}\right)$, Domaszne $\left(51^{\circ} 28^{\prime} \mathrm{N}\right.$, $\left.23^{\circ} 0^{\prime} \mathrm{E}\right)$, Krzczeń $\left(51^{\circ} 23^{\prime} \mathrm{N}, 22^{\circ} 56^{\prime} \mathrm{E}\right)$, Syczyńskie $\left(51^{\circ} 17^{\prime} \mathrm{N}\right.$, $\left.23^{\circ} 14^{\prime} \mathrm{E}\right)$, Sumin $\left(51^{\circ} 22^{\prime} \mathrm{N}, 23^{\circ} 08^{\prime} \mathrm{E}\right)$, Białe Sosnowickie $\left(51^{\circ} 32^{\prime} \mathrm{N}, \quad 23^{\circ} 02^{\prime} \mathrm{E}\right)$ and Dratów $\left(51^{\circ} 20^{\prime} \mathrm{N}, 22^{\circ} 56^{\prime} \mathrm{E}\right)$ (Fig. 1). The morphological parameters and environmental conditions of the lakes are presented in Table 1 .

\section{Water sampling and analysis}

Water samples used for evaluation of habitat conditions were taken simultaneously with macrophytes, in July of 2011, 2012 and 2013. Samples were collected in the middle lake zone, using a $10 \mathrm{dm}^{3}$ tube sampler. In situ, a YSI multiparameter meter was used to record water temperature, Secchi disc depth, dissolved oxygen, $\mathrm{pH}$ and conductivity. At the laboratory, we determined nutrient compounds (N-NH $\left.4, \mathrm{~N}_{4} \mathrm{NO}_{3}, P_{\text {tot }}, \mathrm{P}_{-} \mathrm{PO}_{4}\right)$ and chlorophyll- $a$ (spectrophotometric method) (Golterman, 1969; Hermanowicz et al., 1999).

The trophic state of the lakes was determined using the synthetic trophic state index (TSI) (Carlson, 1977). The TSI was calculated as the average value of concentrations of total phosphorus, Secchi disc visibility and Chl- $a$ according to the formula:

$$
\mathrm{TSI}=\frac{\left(\mathrm{TSI}_{\mathrm{Ptot}}+\mathrm{TSI}_{\mathrm{SD}}+\mathrm{TSI}_{\mathrm{Chl}-a}\right)}{3},
$$

where

$$
\begin{aligned}
\mathrm{TSI}_{\text {Ptot }} & =14^{x} \ln \left(P_{\text {tot }}\right)+4.15 \\
\mathrm{TSI}_{\mathrm{SD}} & =6014.41^{x} \ln (\mathrm{SD}) \text { and } \\
\mathrm{TSI}_{\mathrm{Chl}-} a & =9.81^{x} \ln (\mathrm{Chl} a)+30.6
\end{aligned}
$$




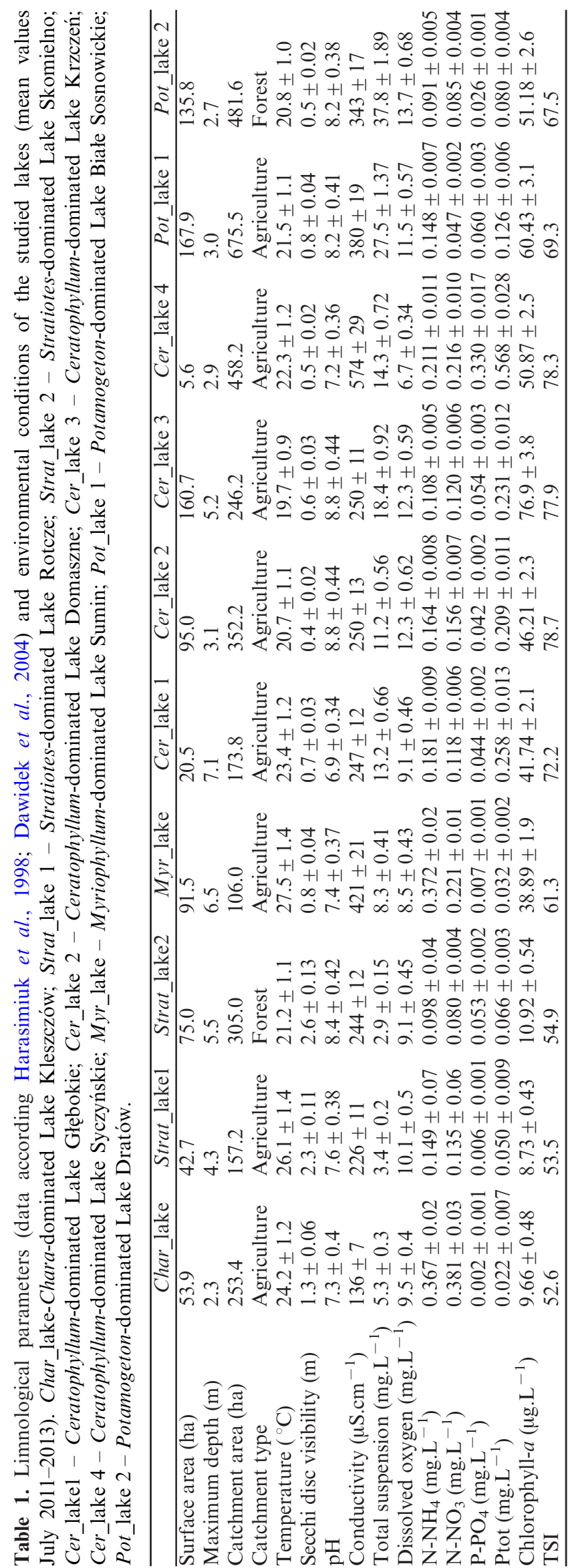

\section{Macrophyte sampling and analysis}

The species structure and spatial distribution of macrophytes were estimated during maximum abundance in July, along horizontal transects according to Jensen (1977). A single transect constituted a minimum width of $30 \mathrm{~m}$ and started from the lake shore to a maximum depth of occurrence of vegetation.

The number of transects varied between 6 and 18 and depended on the surface area of the lake. At each point of a transect, water depth, species presence and macrophyte coverage were estimated using a viewer and a rake. Mean macrophyte coverage was calculated according to the Braun-Blanquet scale and was assigned to the following categories: $0,1-1,1-5,5-25,25-50,50-75$ and $75-100 \%$ coverage. Based on macrophyte-covered area for each transect, we determined total macrophyte cover in the lake.

Macrophyte biomass was sampled by collecting plants at sediment level at an area of $0.16 \mathrm{~m}^{2}$. At each sampling date, three random replicates per lake were taken. Each macrophyte sample was put into a separate plastic bag. At the laboratory, the plants were gently washed under running tap water to avoid damaging plant tissues, and blotted to remove surface moisture. Each sample was washed separately. Next, the plants were put into a $105^{\circ} \mathrm{C}$ for $10 \mathrm{~h}$ to obtain the dry weight (DW).

The species diversity of macrophytes was evaluated using the Shannon-Wiener index, calculated according to the formula (Krebs, 1989):

$$
H^{\prime}=\sum_{i=1}^{s}\left(p_{i}\right)\left(\log _{2} p_{i}\right)
$$

were: $s$ - number of species, $p_{i}$ - proportion of individuals belonging to the $i$ species to the total number of individuals.

\section{Data analysis}

The influence of the lake (defined as a set of environmental conditions) on the total biomass of macrophytes and the area of macrophyte cover was verified using one-way analysis of variance (ANOVA). The relationships between habitat conditions (lake trophic status) and macrophyte diversity and biomass were determined by calculating Pearson correlation coefficients.

The biomass data (matrices) were used to test the effect of lake type on macrophyte structure and percentage cover using principal component analysis (PCA). The effect of habitat conditions (a group of nine environmental variables: Secchi disc depth, conductivity, $\mathrm{pH}$, dissolved oxygen, $\mathrm{N}-\mathrm{NH}_{4}, \mathrm{~N}-\mathrm{NO}_{3}, P_{\text {tot }}, \mathrm{P}_{-} \mathrm{PO}_{4}$, and chlorophyll- $a$ ) on the structure and spatial distribution of submerged macrophytes was verified using partial redundancy analysis (RDA). The PCA and RDA analyses were applied after detrended correspondence analysis (DCA), which indicated the linear species responses to the environmental 


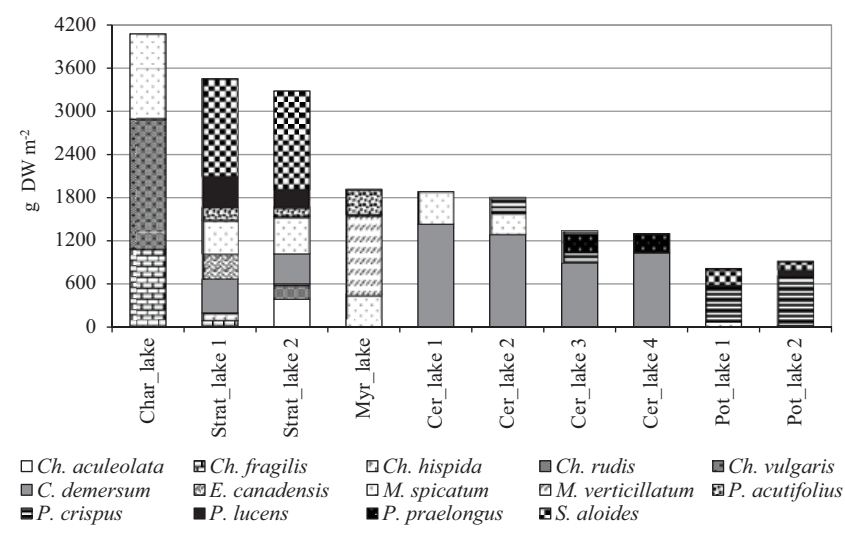

Fig. 2. Total biomass and domination structure of submerged macrophytes in studied lakes (mean values July 2011-2013 per lake; $N=90$ ). For lake abbreviations see Table 1 .

gradient (length of gradient $<2 \mathrm{SD}$ ) (ter Braak and Smilauer, 2002). The Monte Carlo permutation test (499 permutations, full model analysis) was used to determine the variables of significant influence on macrophyte structure and distribution (Lepš and Šmilauer, 2003). The ordination analyses were performed using CANOCO 4.5 for Windows.

\section{Results}

\section{Environmental parameters}

The physical and chemical water parameters of the studied lakes showed high variability (Table 1). Significant differences between the lakes were noted for Secchi disc visibility (ANOVA, $F=11.87 ; P<0.001$ ), total suspension (ANOVA, $F=5.62 ; P<0.001$ ), $\mathrm{N}^{-N_{H}}{ }_{4}$ (ANOVA, $\quad F=10.13 ; \quad P<0.001$ ), $\quad \mathrm{N}^{-\mathrm{NO}_{3}}$ (ANOVA, $F=4.28 ; \quad P<0.015$ ), $\quad$ Ptot $\quad$ (ANOVA, $\quad F=28.94$; $P<0.011$ ), $\mathrm{P}_{-\mathrm{PO}_{4}}$ (ANOVA, $\left.F=53.26 ; P<0.001\right)$ and chlorophyll- $a$ (ANOVA, $F=7.25 ; P<0.001$ ).

\section{Macrophyte structure and biomass}

The studied lakes represent five macrophyte community types: Chara-, Stratiotes, Myriophyllum-, Potamogeton- and Ceratophyllum-dominated. These types differed significantly in terms of total area overgrown by macrophytes (ANOVA, $F=53.18 ; P<0.001$ ) and the total biomass of macrophytes (ANOVA, $F=233.31 ; P<0.001)$. The total biomass ranged from 814.4 g.DW.m ${ }^{-2}$ (Potamogeton-dominated lakes) to 4076.6 g.DW.m ${ }^{-2}$ (Chara-dominated lake) (Fig. 2). The species richness of macrophytes varied between 2 and 8 species and showed the highest values in Stratiotesdominated lakes (Fig. 3). The highest macrophyte cover was observed in Chara-dominated (92\%) and Stratiotesdominated lakes $(67-84 \%)$; the lowest in Potamogetondominated lakes, at the lakes submerged macrophytes overgrown from 7 to $11 \%$ of lake bottom area (Fig. 3).

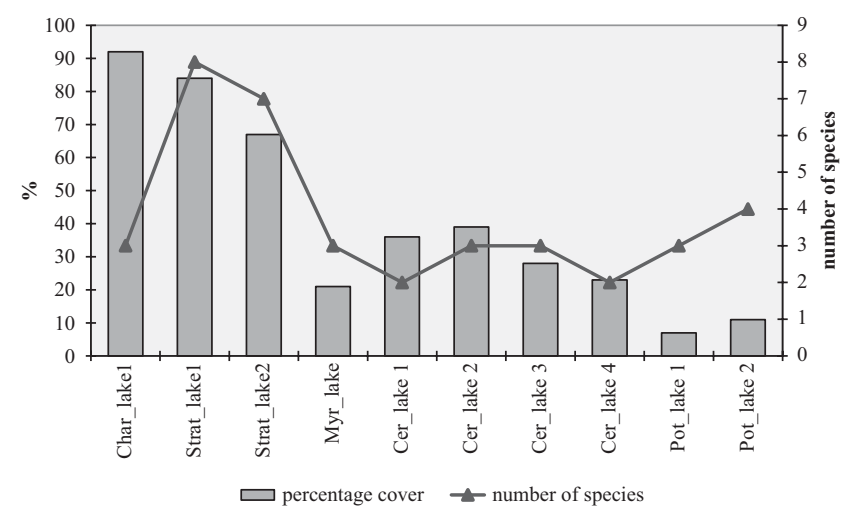

Fig. 3. Percentage cover of submerged macrophytes with regard to the number of species (mean values July 2011-2013). For lake abbreviations see Table 1 .

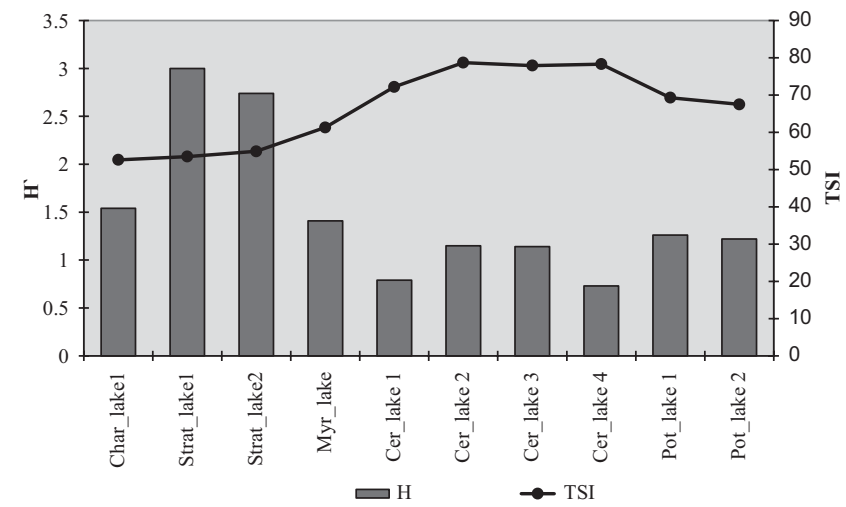

Fig. 4. Species diversity of submerged macrophytes (values of Shannon-Wiener index) with regard to lake trophic status (TSI index) (mean values July 2011-2013). For lake abbreviations see Table 1.

\section{Macrophyte diversity versus lake trophic status}

The diversity of submerged macrophytes (values of the Shannon-Wiener index) differed visibly between the lake types (Fig. 4). Values for the $\mathrm{H}$ index ranged from 0.73 (Ceratophyllum-dominated lake) to 3.0 (Stratiotesdominated lake). Values for the trophic state index were significantly negatively correlated with macrophyte biomass $(r=-0.66 ; P=0.014)$, species diversity $(r=-0.79 ; P=0.006)$ and percentage cover of macrophytes $(r=-0.62 ; P=0.022)$. The lowest values of TSI, 52.6-54.9, were noted in Chara- and Stratiotes-dominated lakes. In Myriophyllum- and Potamogeton-dominated lakes, the trophic state index varied between 61.3 and 69.3, and in Ceratophyllum-dominated lakes, TSI was the highest (72.2-78.7), typical for hypertrophic lakes (Fig. 4).

\section{Ordination analysis}

Axis $1(\lambda=0.426)$ and axis $2(\lambda=0.265)$ of PCA explained $69.1 \%$ of the total variance in macrophyte 
A)

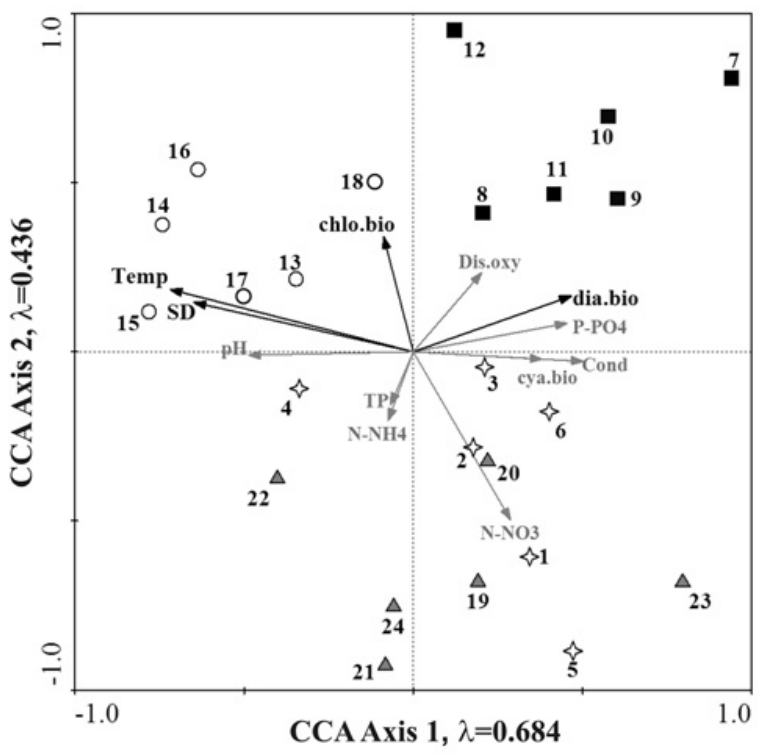

B)

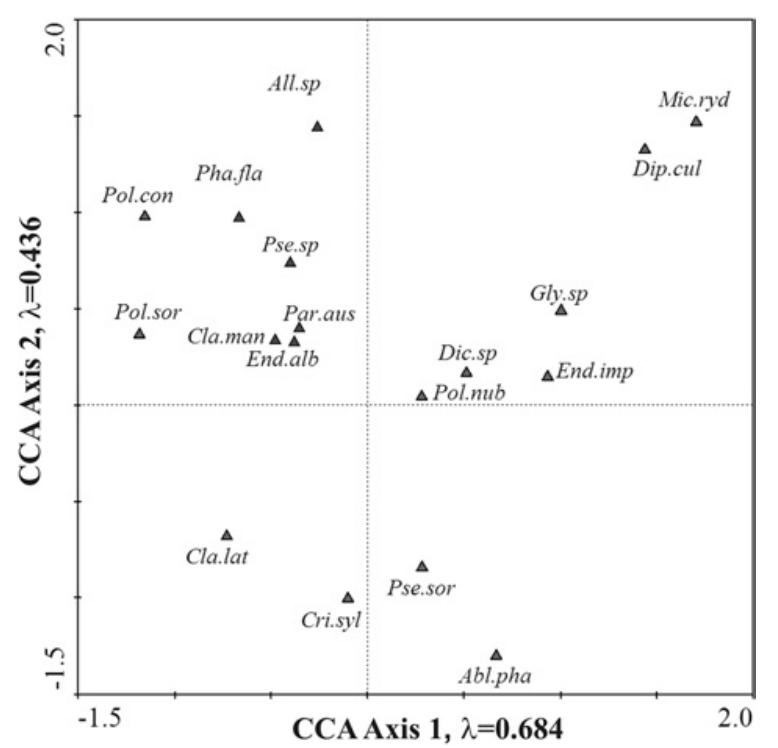

Fig. 5. Principal component analysis (PCA) plot for axis 1 and 2 showing macrophyte samples collected in studied lakes. Axes are derived from the variation in the macrophyte data. Samples collected in studied lakes are marked with an Arabic numeral: 1-9 - Chara-dominated Lake Kleszczów; 10-18 - Stratiotes-dominated Lake Rotcze; 19-27 - Stratiotesdominated Lake Skomielno; 28-36 - Myriophyllum-dominated Lake Sumin; 37-45 - Ceratophyllum-dominated Lake Głębokie Uścimowskie; 46-54 - Ceratophyllum-dominated Lake Domaszne; 55-63 - Ceratophyllum-dominated Lake Krzczeń; 64-72 - Ceratophyllum-dominated Lake Syczyńskie; 73-81 Potamogeton-dominated Lake Białe Sosnowickie; 82-90 Potamogeton-dominated Lake Dratów.

distribution. These two axes showed a clear division of the studied lakes into four groups (Fig. 5). Stratiotesdominated lakes (Group II) were visibly separate from Chara-dominated lakes (Group I), Myrophyllumlakes (Group III) and Group IV, which included Ceratophyllum- and Potamogeton-dominated lakes.

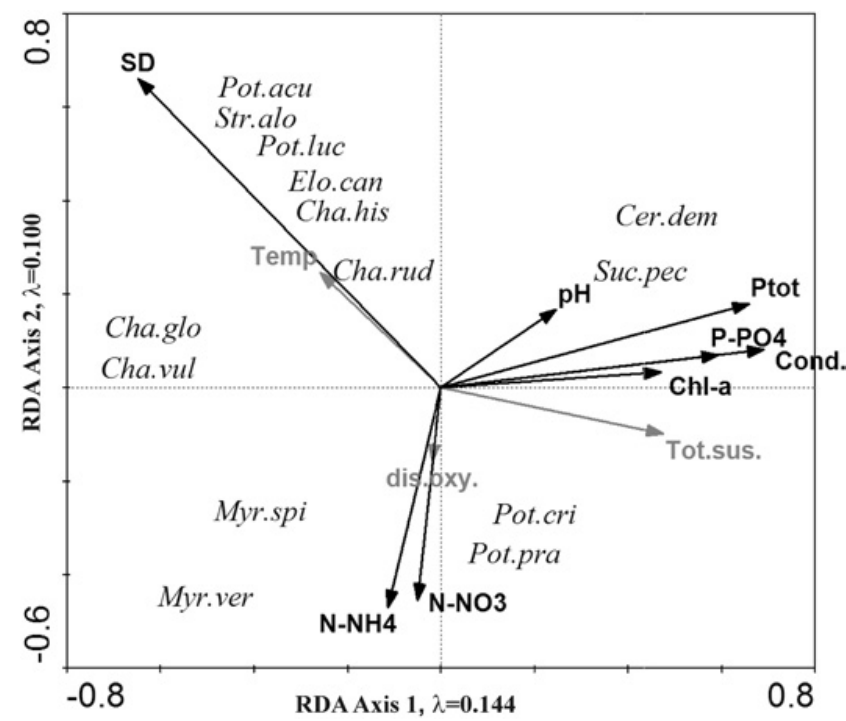

Fig. 6. Redundancy analysis (RDA) biplot for axis 1 and 2 showing macrophyte species biomass and environmental variables. Solid arrows indicate significant variables based on Monte Carlo permutation test $(P<0.05)$. Temp-water temperature; SD - Secchi disc visibility; Cond-conductivity; dis.oxy - dissolved oxygen; $\mathrm{N}-\mathrm{NH}_{4}$ - ammonium nitrogen; $\mathrm{N}-\mathrm{NO}_{3}$ - nitrate nitrogen; $\mathrm{P}-\mathrm{PO}_{4}$ - dissolved orthophosphates; $P_{\text {tot }}-$ total phosphorous; Chl-a - chlorophyll- $a$; tot.sus-total suspension. Cha.glo-Chara globularis, Cha.his-Chara hispida, Cha.rud-chara rudis, Cha.vul-Chara vulgaris, Cer.demCeratophyllum demersum, Elo.can-Elodea canadensis, Myr.spiMyriophyllum spicatum, Myr.ver-Myriophyllum verticillatum, Pot.acu.-Potamogeton acutifolius, Pot.cri-Potamogeton crispus, Pot.luc-Potamogeton lucens, Stu.pec-Stuckenia pectinata, Pot.pra-Potamogeton praelongus, Str.alo-Stratiotes aloides.

The results of RDA confirmed the division of macrophyte species with regard to lake tropic status (Fig. 6). We noted the significant effect of eight environmental variables (results of the Monte Carlo permutation test) on the distribution and biomass of macrophyte species within lake types. Secchi disc visibility $(\lambda=0.11 ; F=10.39$; $P=0.002$ ) showed a significant effect on distribution of large groups of macrophyte species, Chara globularis, Chara hispida, Chara rudis, Chara vulgaris, Elodea canadensis, Stratiotes aloides, Potamogeton acutifolius and Potamogeton lucens. These species are associated with Chara- and Stratiotes-dominated lakes. Chlorophyll- $a$ $(\lambda=0.03 ; \quad F=3.23 ; \quad P=0.018), \mathrm{pH} \quad(\lambda=0.04 ; \quad F=4.92 ;$ $P=0.002), \quad \mathrm{P}_{-} \mathrm{PO}_{4} \quad(\lambda=0.02 ; \quad F=2.69 ; \quad P=0.026)$, Ptot $(\lambda=0.03 ; \quad F=4.09 ; \quad P=0.008)$ and conductivity $(\lambda=0.10 ; F=10.46 ; P=0.004)$ were the determinants of biomass and distribution of Ceratophyllum demersum and Stuckenia pectinata in Ceratophyllum-dominated lakes. However, concentrations of $\mathrm{N}^{-\mathrm{NH}_{4}}(\lambda=0.10$; $F=1.89 ; P=0.012$ ) showed a significant effect on the abundance of Myriophyllum spicatum and Myriophyllum verticillatum, the dominant species in Myriophyllumdominated lakes. $\mathrm{N}^{-\mathrm{NO}_{3}}(\lambda=0.44 ; F=4.09 ; P=0.006)$ was the determinant for the presence of Potamogeton 
crispus and Potamogeton praelongus, both pondweed species typical for Potamogeton-dominated lakes.

\section{Discussion}

Macrophyte assemblages showed great potential as indicators of environmental conditions in shallow lakes. We observed visible changes within macrophyte communities through Chara, Stratiotes, Myriophyllum, Potamogeton up to Ceratophyllum dominance, which reflect the eutrophication process of lake ecosystems.

Chara-dominated lakes are characterized by the highest total biomass of macrophytes (g.DW. ${ }^{-2}$ ). Charophytes, which grow on the bottom of the water column, are known to be negatively affected by nutrient enrichment (van den Bund and van Donk, 2004; Bakker et al., 2010). We also observed a significant effect of Secchi disc visibility on the biomass of macrophytes in the lake. This observation can be related to the results of Egertson et al. (2004), who indicated the importance of light as a limiting factor for the changes in macrophyte composition and relative abundances as a response to increased turbidity due to agricultural eutrophication. Moreover, Chara spp. are known to have an allelopathic effect on algal growth (Mulderij et al., 2003). Studies by Mulderij et al. (2007) showed that the allelopathic activity of Chara spp. may cause a reduction in phytoplankton growth of 5-10\%.

Stratiotes-dominated lakes showed high biomass and species richness of macrophytes. The presence of the macrophyte species Stratiotes aloides is evidence of the good ecological status of a lake ecosystem (Smolders et al., 2003; Pełechaty et al., 2015). As indicated by the study performed by Mulderij et al. (2007), S. aloides has stronger allelopathic activity than Chara spp., which may result in the reduction of phytoplankton biomass even by $80 \%$. Moreover, during the summer, S. aloides often floats on the water and has a potential shading effect on phytoplankton. In addition, this macrophyte species had a considerable effect on the reduction of phosphorus levels in the water.

In Myriophyllum-dominated lakes, the biomass of macrophytes was quite low, observed in highly eutrophic lakes. Eurasian watermilfoil (Myriophyllum spicatum), one of the key species in the lake, is a submerged species exhibiting potent growth and dispersal strategies that enable the plant to rapidly dominate various aquatic systems (Smith and Barko, 1990). Milfoil-dominated lakes usually have low phytoplankton densities (Gross et al., 1996). We observed such a relation in our study. Lower concentrations of planktonic chlorophyll- $a$ in Myriophyllum-dominated lakes were probably a result of the allelopathic effect of Myriophyllum species. $M$. spicatum exhibits a strong inhibitory action against various cyanobacteria, and to a lesser extent to chlorophytes and diatoms (Gross et al., 1996; Körner and Nicklisch, 2002). The production of anticyanobacterial polyphenols has also been reported for another species of the Myriophyllum genus, M. verticillatum (Aliotta et al.,
1992). In the present study, the biomass of Myriophyllum species was significantly related to higher concentrations of nitrogen compounds (especially $\mathrm{N}-\mathrm{NH}_{4}$ ) in water. Large increases in $M$. spicatum biomass, between 30 and $40 \%$, were also observed during experimental studies with ammonium enrichment by Anderson and Kalff (1986). Moreover, studies carried out by Schneider and Melzer (2004) showed that the growth of M. spicatum was positively correlated with high water ammonia concentrations.

Ceratophyllum-dominated lakes showed typical hypertrophic conditions; the dominant species, Ceratophyllum demersum, may even grow where only $1 \%$ of surface water illumination is available (Hutchinson, 1975), which enables its development under high phytoplankton biomass and low water transparency. In the studied Ceratophyllum-dominated lakes, we observed a significant effect of total phosphorus and chlorophyll- $a$ concentrations on the biomass of $C$. demersum (results of RDA analysis), as well as a positive relationship (Spearman correlation coefficient) between the biomass of macrophytes and concentrations of total phosphorus in water. The presence of $S$. pectinata confirms its tolerance for eutrophic conditions (Grassmuck et al., 1995) - the plant forms a canopy to exploit light near the water surface (van den Berg et al., 1999). S. pectinata can tolerate turbid conditions rather well, but most often does not produce high biomass (Bakker et al., 2010; Hidding et al., 2010).

In Potamogeton-dominated lakes, we observed the lowest biomass of macrophytes and low species diversity. In these ecosystems, curly-leaf pondweed Potamogeton crispus dominated. The species is an indicator of eutrophication (Nichols and Shaw, 1986) and is best suited to nutrient-rich water. Curly-leaf pondweed tolerates low light conditions (Tobiessen and Snow, 1984) and turbidity (Nichols, 1992).

In conclusion, the species structure and distribution of submerged macrophytes documented in this study were lake-specific and related to water transparency and the nutrient status of the lake. Moreover, the results of ordination analysis as well as correlation coefficients led us to conclude that abundant growth and high species richness of macrophytes are the combined effect of environmental conditions, such as Secchi disc depth, and concentrations of nutrients and chlorophyll- $a$, specific for a given lake ecosystem.

Acknowledgements. The study was financed by the Dean of the Faculty of Biology and Animal Breeding of the University of Life Sciences in Lublin, Poland as project "Functioning of retention reservoirs supplying from Wieprz-Krzna drainage canal (Łęczyńsko-Włodawskie Lakeland)".

\section{References}

Abdo M.S.A. and Da Silva C.J., 2002. Nutrient stock in the aquatic macrophytes Eichhornia crassipes and Pistia stratiotes in the Pantanal-Brazil. In: Proceedings of the German-Brazilian Workshop on Neotropical Ecosystems, 875-880. 
Aliotta G., Molinaro A., Monaco P., Pinto G. and Previtera L., 1992. Three biologically active phenulpropanoid glucosides from Myriophyllum verticillatum. Phytochemistry, 31, 109-111.

Anderson M.R. and Kalff J., 1986. Nutrient limitation of Myriophyllum spicatum growth in situ. Freshwater Biol., 16, 735-743.

Bakker E.S., van Donk E., Declerck S.A.J., Helmsing N.R., Hiding B. and Nolet B.A., 2010. Effect of macrophyte community composition and nutrient enrichment on plant biomass and algal blooms. Basic Appl. Ecol., 11, 432-439.

Barko J.W., Adams M.S. and Clesceri N.L., 1986. Environmental factors and their consideration in the management of submersed aquatic vegetation-a review. $J$. Aquat. Plant Manag., 24, 1-10.

Canfield D., Shireman J., Colle D., Haller W., Watkins C. and Maceina M., 1984. Prediction of chlorophyll- $a$ concentrations in Florida lakes: importance of aquatic macrophytes. Can. J. Fish. Aquat. Sci., 41, 497-501.

Carlson R.E., 1977. A trophic state index for lakes. Limnol. Oceanogr., 22, 361-369.

Clarke S.J. and Wharton G., 2001. Sediment nutrient characteristics and aquatic macrophytes in lowland English rivers. Sci. Total Environ., 266, 103-112.

Dawidek J., Sobolewski W. and Turczyński M., 2004. Transformations of catchment-areas of lakes converted into storage reservoirs in the Wieprz-Krzna Canal system. Limnol. Rev., 4, 67-74.

Egertson Ch.J., Kopaska J.A. and Downing J.A., 2004. A century of change in macrophyte abundance and composition in response to agricultural eutrophication. Hydrobiologia, 52, 145-156.

Faafeng B.A. and Mjelde M., 1998. Clear and turbid water in shallow Norwegian lakes related to submerged vegetation. In: Jeppesen E., Sondergaard Ma., Sondergaard Mo. and Christofersen K. (eds.), The Structuring Role of Submerged Macrophytes in Lakes, Springer, New York, 361-368.

Golterman H.L., 1969. Methods for Chemical Analysis of Freshwaters, IBP Handbook No. 8. Blackwell Scientific Publications, Oxford, Edinburgh.

Grassmuck N., Haurey J., Leglize L. and Muller S., 1995. Assessment of the bio-indicatory capacity of aquatic macrophytes using multivariate analysis. Hydrobiologia, 300-301, 115-122.

Gross E.M., Meyer H. and Schilling G., 1996. Release and ecological impact of algicidal hydrolysable polyphenols in Myriophyllum spicatum. Phytochemistry, 41, 133-138.

Harasimiuk M., Michalczyk Z. and Turczyński M., 1998. Lakes of Lęczna-Włodawa Lakeland. Environmental Monograph, UMCS Lublin Press, Lublin (in Polish).

Hermanowicz W., Dojlido J., Dożańska W., Kosiorowski B. and Zerbe J., 1999. Physical and Chemical Investigation Methods of Water and Sewage, Arkady Press, Warsaw (in Polish).

Hidding B., Nolet B.A., De Boer T., De Vries P.P. and Klaassen M., 2010. Above- and below-ground vertebrate herbivory may each favour a different subordinate species in an aquatic plant community. Oecologia, 162, 199-208.

Horppila J. and Nurminen L., 2001. Effects of different macrophyte growth forms on sediment and $P$ resuspension in a shallow lake. Hydrobiologia, 545, 167-175.

Hutchinson G.E., 1975. A Treatise on Limnology, Vol. III: Limnological Botany, John Wiley \& Sons, New York.
James C.S., Fisher J., Russell V., Collings S. and Moss B., 2005. Nitrate availability and hydrophyte species richness in shallow lakes. Freshwater Biol., 50, 1049-1063.

Jensen S., 1977. An objective method for sampling the macrophyte vegetation in lakes. Vegetatio, 33, 107-118.

Jeppesen E., Søndergaard M., Meerhoff M., Lauridsen T.L. and Jensen J.P., 2007. Shallow lake restoration by nutrient loading reduction-some recent findings and challenges ahead. Hydrobiologia, 584, 239-252.

Kalff J., 2001. Limnology, Prentice Hall, New York.

Kolada A., Soszka H., Cydzik D. and Gołub M., 2005. Abiotic typology of Polish lakes. Limnology, 35, 145-150.

Kornijów R. and Radwan S., 2002. The principles of sustainable use and conservation of lakes in rural areas. In: Radwan S. (ed.), Problems of Protection and use of Rural Areas of High Natural Values. Maria Curie-Skłodowska Press, Lublin, Poland, 63-70 (in Polish).

Körner S. and Nicklisch A., 2002. Allelopathic growth inhibition of selected phytoplankton species by submerged macrophytes. J. Phycol., 38, 862-871.

Krebs C.H., 1989. Ecological Methodology, Harper \& Row, New York.

Kristensen P., Sondergaard M. and Jeppesen E., 1992. Resuspension in a shallow eutrophic lake. Hydrobiologia, 228, 101-109.

Lepš J. and Šmilauer P., 2003. Multivariate Analysis of Ecological Data using CANOCO, Cambridge University Press, Cambridge.

Mahaney W.M., Wardrop D.H. and Brooks R.P., 2004. Impacts of sedimentation and nitrogen enrichment on wetland plant community development. Plant Ecol., 175, 227-243.

Moss B., Barker T., Stephen D., Williams A.E., Balayla D., Beklioglu M. and Carvalho L., 2005. Consequences of reduced nutrient loading to a shallow and a deep lake in a lowland catchment - deviations from the norm? Freshwater Biol., 50, 1687-1705.

Mulderij G., van Donk E. and Roelofs J.G.M., 2003. Differential sensitivity of green algae to allelopathic substances from Chara. Hydrobiologia, 491, 261-271.

Mulderij G., van Nes E.H. and van Donk E., 2007. Macrophytephytoplankton interactions: the relative importance of allelopathy versus other factors. Ecol. Model., 204, 85-92.

Murphy K.J., 2002. Plant communities and plant diversity in softwater lakes of Northern Europe. Aquat. Bot., 73, 287-324.

Nichols S.A., 1992. Depth, substrate, and turbidity relationships of some Wisconsin lake plants. Trans. Wisconsin Acad. Sci. Arts Lett., 80, 97-118.

Nichols S.A. and Shaw B.H., 1986. Ecological life histories of the three aquatic nuisance plants, Myriophyllum spicatum, Potamogeton crispus, and Elodea canadensis. Hydrobiologia, 131, 3-21.

Pełechaty M., Ossowska J., Pukacz A. and Apolinarska K., 2015. Site-dependent species composition, structure and environment al conditions of Chara tomentosa L. meadows, western Poland. Aquat. Bot., 120, 92-100.

Penning W.E., Mjelde M., Dudley B., Hellsten S., Hanganu J., Kolada A., van den Berg M., Poikane S., Phillips G., Willby N. and Ecke F., 2008. Classifying aquatic macrophytes as indicators of eutrophication in European lakes. Aquat. Ecol., 42, 237-251. 
Rørslett B., 1991. Principal determinants of aquatic macrophyte richness in northern European lakes. Aquat. Bot., 39, 173-193.

Scheffer M., Hosper S.H., Meijer M.L., Moss B. and Jeppesen E., 1993. Alternative equilibria in shallow lakes. Trends Ecol. Evol., 8, 275-279.

Schneider S. and Melzer A., 2004. Sediment and water nutrient characteristics in patches of submerged macrophytes in running waters. Hydrobiologia, 527, 195-207.

Small H., Kornijów R. and Ligęza S., 2005. The effect of catchment on water quality and eutrophication risk of five shallow lakes (Polesie Region, Eastern Poland). Pol. J. Ecol., 53, 313-327.

Smith C.S. and Barko J.W., 1990. Ecology of Eurasian watermilfoil. J. Aquat. Plant Manage., 28, 55-64.

Smolders A.J.P., Lamers L.P.M., den Hartog C. and Roelofs J.G.M., 2003. Mechanisms involved in the decline of Stratiotes aloides L. in The Netherlands: sulphate as a key variable. Hydrobiologia, 506-509, 603-610.

Squires L. and van der Valk A.G., 1992. Water-depth tolerances of the dominant emergent macrophytes of the Delta Marsh, Manitoba. Can. J. Bot., 70, 1860-1867. ter Braak C.J.F. and Šmilauer P., 2002. CANOCO Reference Manual and User's Guide to Canoco for Windows: Software for Canonical Community Ordination (version 4.5), Microcomputer Power, Ithaca, New York, USA.

Tobiessen P. and Snow P.D., 1984. Temperature and light effects on the growth of Potamogeton crispus in Collins Lake, New York State. Can. J. Bot., 62, 2822-2826.

Toivonen H. and Huttunen P., 1995. Aquatic macrophytes and ecological gradients in 57 small lakes in southern Finland. Aquat. Bot., 51, 197-221.

van de Bund W.J. and van Donk E., 2004. Effects of fish and nutrient additions on food-web stability in a charophyte-dominated lake. Freshwater Biol., 49, 1565-1573.

van den Berg M.S., Scheffer M., van Nes E. and Coops H., 1999. Dynamics and stability of Chara sp and Potamogeton pectinatus in a shallow lake changing in eutrophication level. Hydrobiologia, 408, 335-342.

van Geest G., 2005. Macrophyte succession in floodplain lakes. Spatio-temporal patterns in relation to hydrology, lake morphology and management. Thesis, Wageningen University, The Netherlands. 